\title{
Interest Rate as a Link to Investment Decision in Nigeria (Mundell - Flemming Model)
}

\author{
Osundina J.A. (Ph D), And Osundina C. K. \\ (Babcock University, Ilishan - Remo, Ogun State, Nigeria)
}

\begin{abstract}
The link between interest rate and investment decision in Nigeria was investigated in this study using Multiple Linear Regression model. A modified Mundel - Flemming model was used where interest rate was the dependent variable and other variables such as; Gross domestic product, investment level, Government spending, debt and exchange rate were independent variables. We found out that there is no strong empirical evidence that there is a link between interest rate and investment decision in Nigeria. We recommend however that there should be efficient infrastructure and the clamor for Islamic Banking, which is interest rate free should be embraced since it will not hurt investment decisions in any way.
\end{abstract}

\section{Introduction}

The interest rate policy in Nigeria is perhaps one of the most controversial of all financial policies. The reason for this may not be farfetched because interest rate policy has direct link to many other macroeconomic variables most especially investment decision. Interest rates play a crucial role in the efficient allocation of resources aimed at facilitating growth and development of an economy and as a demand management technique for achieving both internal and external balance. The term cyclical volatility of interest rates refers to the variability of interest rates over periods that correspond to the length of the typical business cycle, the variation of interest rates affects decisions about how to save and invest.

Interest rate policy in Nigeria lacked consistency during the Structural Adjustment Program (SAP) as periods of liberalization were intertwined with impositions of some credit controls (IMF, 1997). The business environment, in general, is very risky and uncertain so firms may not be able to service debt. Apart from this, the judicial system is reportedly inefficient and banks cannot easily enforce contracts, consequently, banks charge high interest rates and request for high levels of collateral. In addition to the above, high interest rate in the Nigerian financial system is a reflection of the extremely poor infrastructural facilities and inefficient institutional framework necessary to bring about substantial reduction in the risk associated with financing an extremely traumatized economy (World Bank, 2002).The administration of low interest rate which was intended to encourage investment before the SAP era and during SAP era of 1986 ushered in a dynamic interest rate regime where rates were more influenced by market forces and it failed to yield desired result of stimulating investment growth in Nigeria. All these problems highlighted persist due to the inconsistency of monetary policy and inability to formulate interest rate reform that will be a component of the broad policy package aimed at facilitating financial intermediation and monetary management that can induce investment spending through low interest rate. Against this background, this paper attempts to establish an empirical relationship between investment and other macroeconomic variables, including interest ratesin Nigeria.

The Nigerian macro-economy witnessed different interest rates for different sectors in 1970s through the mid 1980s under regulation between 1960-1985. The preferential interest rates were based on the assumption that the market rate, if universally applied, would exclude some of the priority sectors. Interest rates were, therefore, adjusted periodically with 'invisible hands' to promote increase in the level of investment in the different sectors of the economy. The factors influencing interest rates would obviously vary with the extent of openness of the economy since forces of demand and supply determine it, for a highly opened economy with dynamic and sophisticated financial markets, the uncovered interest parity theory states that the differential between the domestic and foreign interest ratio equals the expected rate of depreciation/appreciation of domestic currency (Horobet, Dumitrescu\&Dumitrescu, 2009).

The effect of real interest rates on private investment spending was first formalized in an investment equation by Jorgenson (1963) in his paper capital theory and investment behavior, who derived the desired stock of capital as a function of real output and the opportunity cost of capital. In this approach, known as the neoclassical approach, a representative firm maximizes the present value of its future cash flows. The desired capital stock is directly related to output and inversely related to the cost of capital a decrease in the real interest rate lowers the opportunity cost of capital and, therefore, raises the desired capital stock and investment spending. The role of financial markets on capital formation (McKinnon, 1973; Shaw, 1973; Fry, 1989), includes suggestions that an increase in the real interest rates has a positive effect on the volume and quality of 
investment in those financially repressed economies like Nigeria. The former effect is given because selffinance is important and investment is lumpy. Then, the economic agents must accumulate resources before any investment project is executed. An increase in real interest rates thus stimulates both total and financial savings and consequently investment. The latter effect, improvement in the quality of investment, occurs because a higher interest rate will rule out investment projects with low productivity. At the same time, higher rates move resources from less efficient (e.g. goods facing some depreciation) to more efficient forms of accumulation (e.g. bank deposits with a more favorable return).In particular, McKinnon (1973), when explaining the link between interest rates, money and investment, suggests a nonlinear relationship between the real interest rates on deposits and the rate of private investment.

Interest rate policy is among the emerging issues in current economic policy in Nigeria in view of the role it is expected to play in the deregulated economy in inducing savings which can be channeled to investment and thereby increasing employment, output and efficient financial resource utilization (Uchendu 1993). Also, interest rates can have a substantial influence on the rate and pattern of economic growth by influencing the volume and disposition of saving as well as the volume and productivity of investment (Leahy, 1993 as cited in Lensink 2000).There is yet no detailed conclusion on the actual link between interest rate and investment whether negative or positive but there is actual link between them. Though, most of the study has been inconclusive, hence this study will tend to examine and establish the past researchers claim.

The long run objective of deregulating the interest rate to promote investment in the agricultural and manufacturing sector of Nigeria was to achieve positive linkage between interest rate and investment in Nigeria in order to foster economic growth and development. The linkage between interest rate and investment in Nigeria by economic scholars call for the need to embark on this study, this study intends to examine what happens to investment with variation in interest rate.

The main objective of the study is to empirically capture the link between interest rate, investment spending and other macroeconomics variables like Gross Domestic Product (GDP), exchange rate, debt and government spending in Nigeria.

\section{Research Hypothesis}

$\mathrm{H}_{0 \text { : }}$ There is no significant relationship between interest rate and macro variables in Nigeria.

The study covered the period of 31 years between 1981 and 2011. Secondary data were employed from Central Bank of Nigeria (CBN) bulletin. The model INT=f(GDP,INV,GOVS,DEBT,EXCH) was estimated through ordinary least square method.

\subsection{Theoretical framework}

\section{Review of Related Literature}

The evolution of investment theory has its origin from Keynes (1936) path breaking work. Keynes argues that investment depends on the prospective marginal efficiency of capital, relative to interest rate which is the opportunity cost of capital to a large extent. He emphasizes the volatility of private investment given the fact that investors cannot predict for a certainty the returns on investment. This then mean that the driving force in investment decision is investors. Keynesian and neoclassical models of investment argue that income and interest rate are important determinants of investment. Subsequent theories of investment after Keynes were basically growth models.

In this approach, optimal capital stock is a function of the level of output and user cost of capital. Lags in decision making and delivery create a gap between current and desired capital stocks, giving rise to an investment equation relating to change in the capital stock. The Keynes and Neo classical arguments are both central to the view expressed by the proponent of the subsisting models of interest rate and investment behaviour determination. The theories of interest rate in relation to investment behaviour will be discussed before the analysis of the model on the two important macro economic variables. We recognized four theories in this work which are; (a) the classical theory, (b) the loan able funds theory (c) the Keynesian theory and (d) the modern theory of interest or the Hicks-Hanson IS-LM Model. This work is however anchored on Mundell Fleming Model.

\subsection{Mundell-Fleming model}

The Mundell-Fleming model, known as the IS-LM-BP model, is an economic model first put together in 1960s by Robert Mundell and Marcus Fleming (Olivier, 2006). The model is an extension of the ISLM model. Whereas the traditional IS-LM Model deals with economy under autarky (or a closed economy), the Mundell-Fleming model describes an open economy. The Mundell-Fleming model portrays the short-run relationship between an economy's nominal exchange rate, interest rate, and output (in contrast to the closedeconomy IS-LM model, which focuses only on the relationship between the interest rate and output). 
The Mundell-Fleming model applied to a small open economy facing perfect capital mobility, in which the domestic interest rate is exogenously determined by the world interest rate, shows stark differences from the closed economy model. Consider an exogenous increase in government expenditure. Under the IS-LM model, the IS curve shifts upward, with the LM curve intact, causing the interest rate and output to rise. But for a small open economy with perfect capital mobility and a flexible exchange rate, the domestic interest rate is predetermined by the horizontal BOP curve, and so by the LM equation given previously there is exactly one level of output that can make the money market be in equilibrium at that interest rate. Any exogenous changes affecting the IS curve (such as government spending changes) will be exactly offset by resulting exchange rate changes, and the IS curve will end up in its original position, still intersecting the LM and BOP curves at their intersection point. The Mundell-Fleming model under a fixed exchange rate regime also has completely different implications from those of the closed economy IS-LM model. In the closed economy model, if the central bank expands the money supply the LM curve shifts out, and as a result income goes up and the domestic interest rate goes down. But in the Mundell-Fleming open economy model with perfect capital mobility, monetary policy becomes ineffective. An expansionary monetary policy resulting in an incipient outward shift of the LM curve would make capital flow out of the economy. The central bank under a fixed exchange rate system would have to instantaneously intervene by selling foreign money in exchange for domestic money to maintain the exchange rate. The accommodated monetary outflows exactly offset the intended rise in the domestic money supply, completely offsetting the tendency of the LM curve to shift to the right, and the interest rate remains equal to the world rate of interest.

\subsection{Literature review}

It is expected that real interest rates play an important role in investment decision making and economic growth. Therefore, economic policy makers in some developing countries have traditionally emphasized on the necessity of keeping interest rates low in order to encourage private sector to invest. Following this approach, the interest rates have been kept at low levels and therefore real interest rates have been negative for long periods. In 1970's, some economists, led by McKinnon (1973) and Shaw (1973), began to support financial liberalization as a medium of promoting saving, investment, and growth. This was based on the argument that real interest rates are frequently negative in developing countries because of administrative controls on the nominal interest rates and heavy regulation in the financial market.

This argument indicates that real interest rates have a net positive impact on private investment, contradicting the traditional view of a negative relationship between private investment and real interest rates. Although, the financial liberalization literature supports higher interest rates, the possibility of a negative relationship between investment and interest rates was not ruled out. McKinnon (1973) argued that in those countries where self-finance is important and the interest rate is negative or very low, an upward increase in real interest rates promotes saving and the substitution from physical assets to bank deposits. His arguments indicate a nonlinear relationship between real interest rates and private investment. Most studies suggest that the macroeconomic environment has an important effect on the stock market capitalization a portfolio investment technique such as gross domestic product, exchange rates, interest rates, current account and money supply (Kurihara, 2006; Ologunde, Elumilade and Saolu 2006).

Maintaining macroeconomic stability has been one of the main challenges for developing countries (Iqbal, 2001). Mahmudul and Gazi (2009) in their study in Jordan on stock investment (based on the monthly data from January 1988 to March 2003) found that interest rate exerts significant negative relationship with share price for markets of Australia, Bangladesh, Canada, Chile, Colombia, Germany, Italy, Jamaica, Japan, Malaysia, Mexico, Philippine, South Africa, Spain, and Venezuela. For six countries from this sample, they argued on the availability of significant negative relationship between changes of interest rate and changes of share price. Aydemir and Demirhan (2009) studied the causal relationship between stock prices and exchange rates, using data from 23 February 2001 to 11 January 2008 for Turkey. Their empirical research found the bidirectional causal relationship between exchange rate and all stock market indices. While the negative causality exists from national 100 service, financial and industrial indices to exchange rate, there exists a positive causal relationship from technology sector indices to exchange rate. On the other hand, negative causal relationship from exchange rate to all stock market indices is determined.

Ologunde et al (2006) examined the relationships between stock market capitalization rate and interest rate in Nigeria. They used the ordinary least-square (OLS) regression method and they found that the prevailing interest rate exerts positive influence on stock market capitalization rate. Part of their findings also, is that Government development stock rate exerts negative influence on stock market capitalization rate and prevailing interest rate exerts negative influence on government development stock rate.

Kurihara (2006) suggests that stock market capitalization rate is significantly influenced by the macroeconomic environment factors such as gross domestic product, exchange rates, interest rates, current account and money supply. Doong, Wang and Yang (2005) investigated the dynamic relationship between 
stocks and exchange rates for six Asian countries (Indonesia, Malaysia, Philippines, South Korea, Thailand, and Taiwan) over the period 1989-2003. According to their study, these financial variables are not co integrated. The result of Granger causality test shows that bidirectional causality can be detected in Indonesia, Korea, Malaysia, and Thailand. Also, there is a significantly negative relation between the stock returns and the contemporaneous change in the exchange rates for all countries except Thailand. Hsing (2004) adopted a structural VAR model that allows for the simultaneous determination of several endogenous variables such as, output, real interest rate, exchange rate, the stock market index and found that there is an inverse relationship between stock prices and interest rate. Zhou (1996) also studied the relationship between interest rates and stock prices using regression analysis. He found that interest rates have an important impact on stock returns, especially in long-term investment horizons, but the hypothesis that expected stock returns move one-for-one with ex ante interest rates is rejected. In addition, his results showed that long-term interest rate explains a major part of the variation in price dividend ratios. Besides, he suggests that the high volatility of the stock market is related to the high volatility of long-term bond yields and may be accounted for by changing forecasts of discount rates.

Some economists argue that when studying investment in developing countries, special features of these countries which are not accounted by traditional theories should be considered. Agenor and Montiel (1996) list some of the factors that can affect private investment in developing countries including; financial variables, exchange rate black market, debt overhang due to possibility of higher tax rate, contribution of public investment and macro economic instability. From the aforementioned factors, the most important determinants of private investment are:

The impact of real interest rates on private investment was first formalized in an investment equation by Jorgenson (1963), who derived the desired stock of capital as a function of real output and the opportunity cost of capital. In this approach, known as the neoclassical approach, a representative firm maximizes the present value of its future cash flows. The desired capital stock is directly related to output and inversely related to the cost of capital. A decrease in the real interest rate reduces the opportunity cost of capital and, therefore, raises the desired capital stock and investment spending. Until 1970, according to the mainstream thought, majority of economists supposed that low interest rates reduces the investment and increases the economic growth. Accordingly, in some developing countries suffering from high unemployment rate, interest rates were kept excessively low in order to stimulate private investment. But, McKinnon and Shaw, on the other hand, view administered low interest rates as detrimental to increased savings and hence investment demand.

Williams (2009), in its findings stipulates that real interest rates were generally negative as a result of the repressed regime prior to 1986, when the rates were fixed and as such brought about financial disintermediation which led to low savings, low investment and low growth in the economy. In the same vein, also in the earlier work of Agu (1988), He pointed out that the central bank is faster than its shadow in its aim to induce the achievement of its objectives through the Structural Adjustment Programme (SAP) which gave birth to the recommendation of deregulation of the economy.

In contrast to with the above opinion, Williams (2009), in its findings stipulates that real interest rates were generally negative as a result of the repressed regime prior to 1986, when the rates were fixed and as such brought about financial disintermediation which led to low savings, low investment and low growth in the economy.

Eregha (2010) examined variations in interest rate and investment determination in Nigeriaand deduced that investment has an indirect relationship with interest rate variation and other variables that he used.

\subsection{Model specification}

\section{Methodology}

In order to establish the link between interest rate and investment spending in Nigeria, the study specifies a modified version of the theoretical hypothesis of Keynesian liquidity preference, the classical and loanable fund theory of interest rate and investment which posit that interest rate behaviour depends on saving (supply of credits),investment (demand for credits),government spending and money supply. The modified version of the model is thus postulated using most of the variables that Eregha (2010) used.

$$
I N T=f(G D P, I N V, G O V S, D E B T, E X C H),
$$

where INT=interest rate, GDP = gross domestic product, GOVS = government spending, DEBT=public debt and EXCH=exchange rate. The model which has been stated is a functional relationship between the above mentioned variables. The model is thus restated in econometric form thus:

$$
I N T=\beta+\phi 1 G D P+\phi 2 I N V+\phi 3 G O V S+\phi 4 D E B T+\phi 5 E X C H+U
$$

\section{Analysis}

\subsection{General description of the data.}

Real GDP has been growing at a steady rate from 1980 to 2010 at the average of about $40 \%$ and above growth rate according to CBN statistical bulletin. The trend of investment in Nigeria between 1980 to 2010 is 
not buoyant, investment increase by 3.8 in 1981 and by 56.6 in 1982 and fall by 1.12 in 1983,1984 rise by $7.3,1985$ by $5.6,1986$ by $26.9,1987$ by 5 and fall in $1989-1990$ by 10 and $5 \%$ respectively.

From 1991 to 2000,investment increased slightly by about average of about $20 \%$,from 2001 to 2003,it increased by about $15 \%$ and 2004 by 28.4 and $27.2 \%$ in 2005.In 2006 it declined by $25 \%$ and increase by $5.4 \%$ from 2007 to 2010 . From 1980 to 1981 , government spending increased by $34.2 \%, 1982$ fall by $2.91 \%$ and increased by $5 \%$ in 1983 and later fall in 1984 by $36.3 \%, 1984-1986$ by average of $11.7 \%$,it remained stagnant in 1986- 1987.

It increased steadily from 1988 to 2007 and declined by $24.17 \%$ in 2008 and later increased by $6.5 \%$ between 2008 and 2010. The debt increased steadily from 1980 to 2010 at an average growth rate of about 24.7 \% from $1980-1988$ and remain stagnant till 1989 but later rose by 44\% in 1990. It increased at a steady rate from 1991 to 2010 at about $47 \%$.

Nigeria Exchange Rate increased from 1980-1985 by $10.43 \%$ and also increased by average of $49.7 \%$ from 1986 to 1993. It decreased from 1993 to 1994 by $0.8 \%$,it remained stagnant from 1994 to 1998 and later increased by $76.4 \%$ in 1999 .

From 2000 to 2001 it decreased by $8.8 \%$ and later increased by average of about $6.93 \%$ from 2002 to 2010 .

The interest rate trend in Nigeria increased at a low rate between 1980 to 1981 by $0.05 \%$,by $0.015 \%$ in 1982 and decreased by $0.025 \%$ in 1983 and rose by $11.53 \%$ in 1984 and declined by $0.125 \%$ in 1985 .In 1986,it increased by 0.025 and increased by $37.5 \%$ in 1987 ,decreased by 9.25 in 1988 .

It increased between 1989 to 1990 and later decreased by 37.5\% in 1991.Between $1992-1993$ it increased and declined in 1993 but remained stable between 1995 - 1996.This rise and fall trend continued till 2008 but fall by $9.57 \%$ in 2009 and remained stable till 2010 .

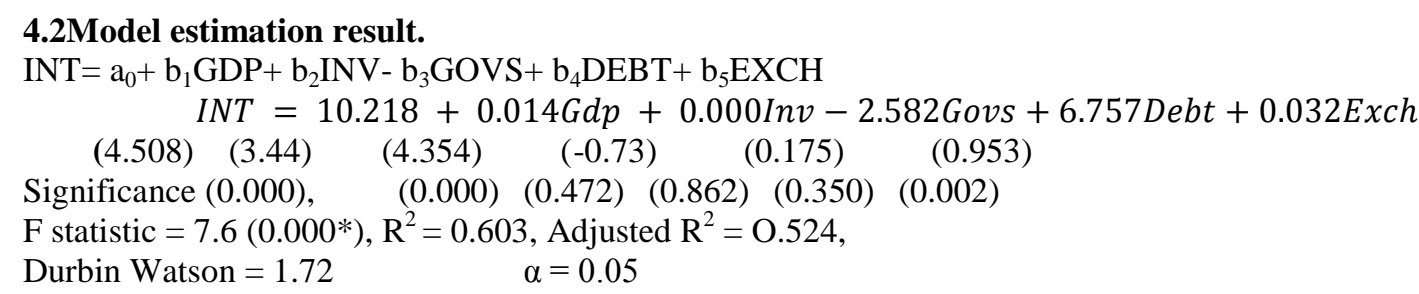

\subsection{Interpretation of Result}

The model stated above is significant at 0.05 levels of significance, this means that we are $95 \%$ confident that type I and II errors were not committed and we can conclude that interest rate and investment are significantly related. From the model above, if investment variables are not taken into consideration, the interest rate in Nigeria stands at $10.22 \%$ which is relatively okay. The economic growth in Nigeria, proxied by GDP has a direct and significant relationship with interest rate in Nigeria which is different from expectation.Considering the $t$ test, the level of significance of the explanatory variables shows that investment and GDP are significant at $5 \%$ levels of significance while public debt, exchange rate, government spending and GDP are not significant.

The co efficient of determination $R^{2}$ is 0.603 i.e. $60.3 \%$ percent while adjusted $R^{2}$ is $0.524, R^{2}$ discloses the explanatory power of the joint variables. It shows that the predictors jointly explain about $60.3 \%$ of the variation in interest rate. The remaining $39.7 \%$ may be explained by other variables outside the model. these variables may include; saving, share of price for market, stock market, government development stock and public investment can make up for the variation if included in the model.

The Durbin Watson (DW) statistic in the result is 1.721 and so makes the result to be free of positive and negative auto correlation. The DW test was carried out to check for the evidence of "Auto correlation".

However, GDP, exchange rate and public debt have positive relationship with interest rate. While, interest rate has negative relationship with government spending and lastly there is no relationship between interest rate and investment. If investment rate increases by one naira Interest rate will increase by $0.000 \%$. This means that investors in Nigeria are no longer affected by the interest rate may be because of the regular fluctuations and have built a buffer in order for their investment to thrive.

\subsection{General discussion of result.}

The result of this research work showed that interest rate has no relationship with investment spending in Nigeria which conform with Mckinon (1973) argument that indicate a non linear relationship between real interest rate and private investment. It is statistically reliable according to the significance test conducted on the estimated result of the model. This assertion is in sharp contrast with some Economists opinions, led by McKinnon (1973) and Shaw (1973), who began to support financial liberalization as a medium of promoting saving, investment, and growth. This was based on the argument that real interest rates are frequently negative 
in developing countries because of administrative controls on the nominal interest rates and heavy regulation in the financial market.

This argument indicates that real interest rates have a net positive impact on private investment, contradicting the traditional view of a negative relationship between private investment and real interest rates. Although, the financial liberalization literature supports higher interest rates, the possibility of a negative relationship between investment and interest rates was not ruled out. McKinnon (1973) argued that in those countries where self-finance is important and the interest rate is negative or very low, an upward increase in real interest rates promotes saving and the substitution from physical assets to bank deposits. However, at extremely high rates, investment in physical capital would be expected to yield a negative or low return. Therefore, at high interest rates, investment and interest rates are expected to be negatively related.

The result also showed that there is negative relationship between interest rate and governmentspending in Nigeria but it is not statistically significant

\section{Policy Recommendation}

The research work assess the link between interest rate and investment expenditure in Nigeria using variables like ; interest rate, investment, government spending, public debt, exchange rate and GDP at factor cost from 1980 to 2010.It adopted the multiple regression method of econometrics to estimate the data collated from CBN statistical bulletin.

The study found that interest rate and investment spending are not related, meaning there is no strong evidence to stress that there is empirical relationship between interest rate and investment expenditure.

Despite the claim that there is no link between interest rate and investment spending, there are many opinions that emphasize they are both related either directly or indirectly to foster economic growth in Nigeria.

The results show that there exist a unique long-run relationship between interest rates and economic growth. Therefore, as a prerequisite for economic growth, government must embark on growth enhancing reforms and be sensitive to the behavior of interest rates in the economy. This will inform the formulation of policy for private sector development as a catalyst for overall economic growth in Nigeria.

Possible policy directions might include encouraging the supply of investment funds through significantly reducing the rate of personal taxation and, consequently, granting incentives for creation of wealth; favoring control of interest rate to stimulate the growth of the stock market; improving the regulatory environment.

Only the interest rate policy that can attract savings mobilization and encourage domestic investment will help the economy.

The significance of the level of income to increased investment cannot be over emphasized as the level of income determines the level of savings which determine investment that can be made to increase mechanized agricultural production in Nigeria.

The study recommends that nothing can hurt investment more than an uncertain or highly volatile macroeconomic environment. Perhaps, of great importance for the profitability of investment are the issue of efficient infrastructures and the availability of skilled labour. The clamor for Islamic banking (zero interest rate) by the current $\mathrm{CBN}$ governor should be given an open arm since interest rate based on the findings of this work are not related. Therefore the existence of Islamic Banking (zero interest rate) cannot be detrimental to Investment in Nigeria. It can be concluded that there is no strong evidence to stress that there is empirical relationship between interest rate and investment expenditure in Nigeria. This study is in line with the general consensus that the relationship between interest rate and investment base on various empirical studies are inconclusive which make them not to conclude whether there exist any relationship between interest rate and investment in real sense.

\section{References}

[1]. Agenor, P. and Montiel P.,(1996). Development Macroeconomics. Princeton: PrincetonUniversity Press.

[2]. Agu, C.C., (1988). Nigerian Banking Structure and Performance: The Banking System Contribution to Economic Development studies. Onitsha African FEP Publishers

[3]. Aydemir, O., Demirhan, E., (2009). "The relationship between stock prices and exchange rates: Evidence from Turkey," International Research Journal of Finance and Economics, Issue 23, pp.207-15.

[4]. CBN (2002). Central Bank of Nigeria: Annual Report and Statement of Accounts, p.47

[5]. CBN, (2000). Central Bank of Nigeria Annual Report and Statement of Account for the Year Ended $31^{\text {st }}$ December. Retrieved from: http://www.centralbank. org, (Accessed on: 23 November, 2010).

[6]. CBN, (2006). Monetary Credit, Foreign Trade and Exchange Policy Guidelines for 2000 Fiscal Year, Monetary Policy Circular Publication. No. 34. Retrieved from: http://www.cbn-treasury.gov.ng, (Accessed on: March 3).

[7]. Central Bank of Nigeria, (2010). Annual Report \& Statement of Accounts, p.100

[8]. Central Bank of Nigeria (2010). Statistical Bulletin, p.27.

[9]. Central Bank of Jordan, Annual reports for 1990-2008, Amman, Jordan.

[10]. Doong, S.-Ch., Yang, Sh.-Y., Wang, A.,( 2005). "The dynamic relationship and pricing of stocks and exchange rates: Empirical evidence from Asian emerging markets," Journal of American Academy of Business, Cambridge, Vol.7, No1, pp.118-23.

[11]. Eregha, P.B. (2010). Interest Rate Variation And Investment Determination In Nigeria, International Business Management, 4 (2), Pp. 41-46 
[12]. Fry, M., (1989). Foreign Debt Instability: An Analysis of National Savings and Domestic Investment Response to Foreign Debt Accumulation in 28 Developing Countries. J. Int. Money Finance.

[13]. Horobet A., Dumitrescu S. and Dumitrescu D. (2009). Uncovered Interest Parity and Financial Market Volatility, The Romanian Economic Journal (2) (32) 21- 45.

[14]. Hsing, Yu.,(2004). "Impacts of fiscal policy, monetary policy, and exchange rate policy on real GDP in Brazil: A VAR model," Brazilian Electronic Journal of Economics, Vol.6, No1.

[15]. Iqbal, Z., (2001). "Economic challenges in the Middle East and North Africa: An overview," Macroeconomic Issues and Policies in the Middle East and North Africa, IMF

[16]. Jorgenson, D. (1963). Investment Vol. 1: Capital theory and investment behavior, MIT Press, 55 Hayward Street, Cambridge, MA 02142 - 1315 USA.

[17]. Kurihara, Y.,(2006). "The relationship between exchange rate and stock prices during the quantitative easing policy in Japan," International Journal of Business, Vol.11, No4, pp.375-86.

[18]. Lensink Robert, (2000). Does Does Financial Development Mitigate Negative Effects of Policy Uncertainty on Economic Growth?Credit Research Paper 00/1

[19]. Mahmudul, A., Gazi Salah, U., (2009). "The relationship between interest rate and stock price: Empirical evidence from developed and developing countries," International journal of business and management, Vol.4, No3, pp.43-51.

[20]. Mckinnon, R. and Shaw, (1973). Money and Capital in International Development. The Brokenness Institution, Washington D.C.

[21]. Mckinnon, R.I., (1973). Money and Capital in Economic Development. 1st Edn., Brookings Institution, Washington D.C., USA.

[22]. Olivier Blanchard, (2006). Macroeconomics, Fourth Edition, Pearson International Edition, Pearson Prentice Hall, Upper Saddle River, Pp. 421-436.

[23]. Ologunde, A., Elumilade, D., Saolu, T., (2006). "Stock market capitalization and interest rate in Nigeria: A time series analysis," International Research Journal of Finance and Economics, Issue 4, pp.154-67.

[24]. Shaw, E. (1973). Financial Deepening in Economic Development. Oxford University Press, London.

[25]. Uchendu, O.A. (1993). "Interest Rate Policy, Savings and Investment in Nigeria", Central Bank of Nigeria Economic and Financial Review, 31(3) : 34-52.

[26]. Williams, E., (2009). The Return of Interest Rate Caps. Business World Publication, May 17.

[27]. World Bank, (1993). World Bank Policy. Res. Bull., 4(3), May-July.

[28]. WIR, (2003). World Investment Report 2001: Promoting Linkages, New York and Geneva.

[29]. WIR, (2009). World Investment Report 2002: Transnational Corporations and Export.

[30]. Zhou, C., (1996). Stock Market Fluctuations and The term Structure. Board of Governors of the Federal Reserve System, Finance and Economics Discussion Series: 96/03. 